\title{
Pengaruh Model Pembelajaran Kooperatif Tipe Teams Games Tournament Berbantuan Permainan Tradisional terhadap Hasil Belajar Anak SD
}

\author{
Nanda Fauzia Abda'u ${ }^{1}$, Fattah Hanurawan ${ }^{2}$, Sutarno $^{3}$ \\ ${ }^{1}$ Pendidikan Dasar-Universitas Negeri Malang \\ ${ }^{2}$ Psikologi Pendidikan-Universitas Negeri Malang \\ ${ }^{3}$ Kependidikan Sekolah Dasar dan Prasekolah-Universitas Negeri Malang
}

\begin{abstract}
INFO ARTIKEL
Riwayat Artikel:

Diterima: 23-07-2019

Disetujui: 13-01-2020

\section{kata kunci:}

teams games tournament; traditional game;

learning outcomes; teams games tournament; permainan tradisional; hasil belajar

ABSTRAK

Abstract: This study aims to determine the differences in student learning outcomes by applying the TGT model assisted by traditional games in the experimental class and student learning outcomes by applying conventional models to the control class. This study used a quasi experimental design with pretest-posttest control group design. The research data was collected using test instruments for learning outcomes in the form of pretest and posttest values. The results showed that there was a significant influence on the Teams Games Tournament learning model assisted by traditional games on student learning outcomes.

\begin{abstract}
Abstrak: Penelitian ini bertujuan guna mengungkapkan pengaruh hasil belajar siswa dengan menerapkan model Teams Games Tournament berbantuan permainan tradisional pada kelas eksperimen dan hasil belajar siswa yang menerapkan model konvensional pada kelas kontrol. Penelitian ini menggunakan desain quasi eksperimental dengan rancangan pretest-posttest control grup design. Data penelitian dikumpulkan dengan menggunakan instrumen tes untuk hasil belajar yang berupa nilai pretest dan posttest. Teknik analisis data yang digunakan dalam penelitian ini yaitu Gain Score Independent sample t-test. Hasil penelitian menunjukkan ada pengaruh yang signifikan model pembelajaran Teams Games Tournament berbantuan permainan tradisional terhadap hasil belajar siswa.
\end{abstract}

\author{
Alamat Korespondensi: \\ Nanda Fauzia Abda'u \\ Pendidikan Dasar \\ Universitas Negeri Malang \\ Jalan Semarang 5 Malang \\ E-mail:nanda.abdau@gmail.com
}

Pembelajaran tematik merupakan pembelajaran yang terdapat pada kurikulum 2013. Pembelajaran tematik merupakan pembelajaran terpadu, dimana dalam satu pembelajaran memuat beberapa mata pelajaran. Menurut (Forgaty \& Robin, 1991) model pembelajaran terpadu adalah sistem pembelajaran yang memuat konsep serta prinsip-prinsip keilmuan secara holistik, bermakna dan otentik yang mampu dan ditemukan oleh siswa secara aktif. Ciri utama dari pembelajaran tematik yaitu pembelajaran terintegrasi dimana beberapa mata pelajaran disajikan dalam bentuk buku bertema. Menurut (Majid, 2014) pembelajaran tematik adalah suatu pendekatan pembelajaran dari beberapa bidang studi yang digabungkan dalam suatu konsep dalam bentuk tema. Pembelajaran tematik yang menyajikan pengumpulan konsep dari beberapa bidang studi memberikan manfaat dalam pembelajaran. Manfaat dari pembelajaran tematik menurut (Hosnan, 2014) yaitu menghemat materi pembelajaran, siswa mampu mengenal menghubungkan konsep secara bermakna, pembelajaran tidak tercepecah-pecah, dan penguasaan konsep pada siswa akan semakin baik dan meningkat. Banyaknya manfaat yang didapatkan dalam pembelajaran tematik merupakan salah satu faktor dari diterapkannya pembelajaran tematik di sekolah dasar. Satu tema dalam pembelajaran tematik memuat beberapa sub tema salah satunya pada buku kelas IV SD tema 1 Indahnya Kebersamaan. Pada tema 1 Indahnya Kebersamaan terdapat tiga sub tema yaitu keberagaman budaya bangsaku, kebersamaan dalam keberagaman, dan bersyukur atas kebersamaan.

Sub tema keberagaman budaya bangsaku memuat materi tentang berbagai macam kebudayaan di Indonesia salah satunya yaitu permainan tradisional. Permainan tradisional adalah permainan anak-anak yang diwarisi secara budaya dari generasi di masa lalu., serta banyak mempunyai variasi. Ada tiga permainan tradisional yang terdapat pada subtema keberagaman budaya bangsaku yaitu benteng-bentengan, gobak sodor, dan telepon kaleng. Permainan tradisional memiliki banyak manfaat bagi pertumbuhan dan perkembangan bagi anak. Manfaat ini telah dibuktikan dengan penelitian yang dilakukan oleh (Lusiana, 2012) menyatakan bahwa permainan tradisional efektif digunakan untuk membangun karakter kejujuran pada 
anak. (Happidin \& Yenina, 2016) menyatakan bahwa permainan tradisional dapat meningkatkan karakter positif anak. (Andriani, 2012) menyatakan bahwa permainan tradisional dapat mengembangkan aspek pengembangan moral, nilai agama, sosial, bahasa, dan fungsi motorik pada anak.

Hasil observasi awal yang dilakukan peneliti di SDN Klojen Kota Malang pada tanggal 9-10 April 2018 di kelas IV B pada saat pembelajaran berlangsung diperoleh data bahwa pemahaman siswa masih rendah tentang pelajaran tersebut, terlihat siswa yang kurang aktif dan ada beberapa siswa yang hanya duduk terdiam selama pembelajaran berlangsung. Guru menggunakan metode ceramah dan penugasan secara berkelompok serta mengajar tanpa menggunakan media pembelajaran sepanjang proses pembelajaran sehingga pembelajaran kurang bermakna. Data tersebut didukung dengan hasil wawancara dari guru kelas IV B yang menyampaikan bahwa "Banyak siswa yang masih kurang aktif dalam pembelajaran". Hal ini terlihat dari aktivitas siswa saat berdiskusi kelompok dalam mengerjakan tugas. Dari lima anggota kelompok hanya dua anggota saja yang aktif mengerjakan sedangkan yang lain masih terlihat diam dan tidak mau membantu dan bekerja sama. Sehingga pemahaman yang diperoleh masih kurang dan masih banyak siswa yang memperoleh hasil belajar di bawah Kriteria Ketuntasan Minimum. Dari hasil observasi dan wawancara yang dilakukan peneliti di SDN Klojen Kota Malang dapat disimpulkan bahwa siswa kurang aktif dalam pembelajaran dan hasil belajar yang diperoleh terdapat 15 siswa dari 25 siswa yang mendapatkan nilai di bawah Kriteria Ketuntasan Minimum.

Kegiatan pembelajaran yang dilakukan harus sesuai dengan materi pembelajaran. Untuk mengajarkan materi dalam pembelajaran diperlukan model pembelajaran yang membuat siswa aktif dan kreatif. Model pembelajaran digunakan agar pembelajaran di kelas lebih terstruktur. Ada beberapa model pembelajaran yang bisa dilakukan untuk pembelajaran dengan menggunakan permainan di dalamnya, salah satunya yaitu model pembelajaran kooperatif. Kegiatan pembelajaran pada model pembelajaran kooperatif lebih menekankan pembelajaran kelompok dimana setiap anggota kelompok dipilih secara acak tanpa membedakan kemampuan dari masing-masing individu. Menurut (Amri, Sofan, \& Ahmadi, 2010) model pembelajaran kooperatif merupakan model pengajaran dimana siswa yang memiliki kemampuan berbeda belajar dalam kelompok-kelompok kecil. Salah satu tipe model pembelajaran kooperatif yaitu TGT (Teams Games Tournament).

Teams Games Tournament biasanya dilakukan dalam pembelajaran dengan kegiatan bekerjasama dalam tim atau kelompok. (Hanurawan, 2009) fungsi utama dari model pembelajaran kooperatif tipe Teams Games Tournament yaitu mempersiapkan siswa untuk melakukan yang terbaik pada saat melakukan game dan tournament. (Gee \& James, 2008) menyatakan bahwa pembelajaran yang baik membutuhkan partisipasi aktif dalam kelompok sosial untuk membantu siswa memahami pengalaman mereka dengan cara tertentu. Belajar secara berkelompok dapat memudahkan siswa dalam memahami suatu materi. Hal ini sejalan dengan teori belajar Vygotsky yang mengedepankan interaksi sosial dalam belajar. Interaksi sosial teori belajar Vygotsky dijelaskan dalam zona perkembangan proksimal dan scaffolding. Teori ZPD Vygotsky yang terpenting ialah penekanan terhadap hakikat pembelajaran sosiokultural, dimana pembelajaran terjadi ketika siswa bekerja dalam zona perkembangan proksimal mereka. Zona perkembangan proksimal menurut (Slavin, 2006) menggambarkan tugas yang masih belum dipelajari seorang siswa tetapi dapat dikerjakan dengan bantuan teman atau orang dewasa yang lebih kompeten. Konsep scaffolding merupakan pendapat Vygotsky tentang pembelajaran sosial. Bantuan tersebut bersifat sementara ketika siswa sudah mulai memahami dan menguasai suatu pengetahuan bantuan tersebut dihilangkan untuk memberikan siswa tanggung jawab penuh. Konsep ZPD dan scaffolding yang telah dijabarkan mencirikan model kooperatif berlandaskan pada teori belajar kontruktivisme sosial.

Hasil Penelitian sebelumnya mengenai pembelajaran kooperatif tipe Teams Games Tournament yaitu penelitian oleh (Rahayu, Galih, Nugraha, \& Feby, 2017) menunjukkan bahwa belajar dengan menggunakan model Teams Games Tournament meningkatkan rasa persatuan dan kesatuan siswa tanpa membedakan suku, ras, agama, dan budaya. (Istiqomah, 2016) dalam penelitian yang dilakukan bahwa penerapan model pembelajaran Teams Games Tournament selain dapat meningkatkan hasil belajar juga dapat meningkatkan motivasi belajar siswa. (Sanusi, Widyaningsih, \& Fitri, 2014) menyatakan bahwa pembelajaran dengan menggunakan model Teams Games Tournament meningkatkan kemampuan komunikasi siswa. Kemampuan yang diperoleh siswa dalam belajar tersebut menunjukkan bahwa penggunaan model Teams Games Tournament dalam pembelajaran sangat efektif dan memudahkan siswa berperan aktif. Hal ini dibuktikan melalui penelitian yang dilakukan oleh (Indrayani, Degeng, \& Sumarmi, 2017) bahwa penggunaan model Teams Games Tournament dalam pembelajaran dapat menciptakan proses pembelajaran yang aktif dan menyenangkan. Sejalan dengan itu, penelitian oleh (Suaeb, Degeng, \& Amirudin, 2018) menyatakan bahwa penggunaan model Teams Games Tournament dalam pembelajaran membuat siswa bersemangat dalam belajar dan memudahkan siswa dalam belajar sehingga hasil belajar siswa meningkat.

Model pembelajaran Teams Games Tournament berbantuan permainan tradisional dapat membantu guru untuk menumbuhkan rasa kerjasama siswa dalam kelompok. (Veloo et al., 2016) menggungkapkan bahwa penerapan pembelajaran TGT merupakan salah satu pendekatan pengajaran yang melibatkan kerja kelompok di kelas, dimana siswa didorong untuk saling membantu dalam menyelesaikan tugas yang diberikan. Penerapan model pembelajaran Teams Games Tournament berbantuan permainan tradisional juga dapat memotivasi siswa dalam belajar sehingga siswa belajar lebih aktif dan menyenangkan melalui kegiatan pembelajaran yang mengaitkan materi pembelajaran dengan permainan tradisional. Dengan demikian, penerapan model pembelajaran Teams Games Tournament berbantuan permainan tradisional dapat menumbuhkan rasa kerjasama antar kelompok sehingga siswa menjadi lebih aktif dan menciptakan pembelajaran yang bermakna dan menyenangkan. 


\section{METODE}

Metode penelitian yang digunakan dalam penelitian ini adalah penelitian eksperimen. Jenis penelitian eksperimen yang digunakan pada penelitian ini yaitu quasi eksperimen dengan rancangan pretest-posttest control grup design. Penelitian ini dilaksanakan di SDN Klojen-Malang dengan subjek penelitian, meliputi siswa kelas IV SDN Klojen-Malang terdiri dari dua kelas yaitu kelas B dan kelas C, yang masing-masing terdiri dari 25 siswa. Adapun kelas IV-C sebagai kelas eksperimen dengan diterapkannya model pembelajaran Teams Games Tournament berbantuan permainan tradisional dan kelas IV-B sebagai kelas kontrol dengan model pembelajaran konvensional.

Variabel dalam penelitian ini yaitu, (1) model pembelajaran Teams Games Tournament berbantuan permainan tradisional sebagai variabel independen (bebas) dan (2) hasil belajar sebagai variabel dependen (terikat). Instrumen yang akan digunakan untuk mengumpulkan data hasil belajar yaitu tes yang berupa soal pretest dan posttest baik di kelas eksperimen dan kelas kontrol. Metode analisis pada penelitian ini menggunakan analisis deskriptif statistik. Pada uji hipotesis dilakukan dengan Gain Score Independnet Sample t-Test dengan bantuan SPSS 20.1 for windows. Sebelum melakukan analisis data dan uji hipotesis, maka terlebih dahulu melakukan uji prasyarat yang dilakukan dengan uji normalitas dan homogenitas varian.

\section{HASIL}

Penelitian dilakukan kepada siswa kelas IV SDN Klojen Kota Malang dengan sampel kelompok eksperimen kelas IV C dengan jumlah siswa 25 dan sampel kelompok kontrol kelas IV B dengan jumlah siswa 25 siswa. Data yang diperoleh berupa data pretest dan posttest. Data akan digunakan untuk mendeskripsikan data secara kuantitatif sehingga akan diperoleh kesimpulan hasil penelitian untuk pengujian hipotesis. Adapun hasil perhitungan pretest kelas eksperimen dan kelas kontrol dapat dilihat pada tabel 4 .

Tabel 1. Hasil Pretest Kelas Eksperimen dan Kelas Kontrol

\begin{tabular}{lccccc}
\hline \multicolumn{1}{c}{ Variabel } & N & Mean & Skor Max & Skor Min & Std. Deviasi \\
\hline Hasil Belajar Pretest Kelas Kontrol & 25 & 13,84 & 24 & 4 & 5,194 \\
Hasil Belajar Pretest Kelas Eksperimen & 25 & 17,84 & 25 & 8 & 5,194 \\
\hline
\end{tabular}

Berdasarkan tabel 1 diketahui bahwa perolehan hasil pretest di kelas eksperimen yang memperoleh rata-rata skor 17,84 dengan perolehan nilai rata-rata 45,10. Sementara data hasil pretest kelas kontrol skor rata-rata 13,84 dengan perolehan nilai rata-rata 34,6. Data hasil pretest siswa menunjukkan hampir semua siswa baik kelas kontrol maupun kelas eksperimen memperoleh rata-rata hasil pretest $>8$ dan $<16$. Dari data hasil pretest kelompok kontrol dan kelompok eksperimen tersebut dapat disimpulkan bahwa hasil belajar dalam kategori rendah.

Data posttest merupakan hasil belajar siswa setelah diberikan perlakuan model pembelajaran kooperatif tipe Teams Games Tournament berbantuan permainan tradisional pada kelas eksperimen dan model konvensional di kelas kontrol. Posttest diberikan untuk mengukur kemampuan siswa dari awal hingga akhir pembelajaran. Adapun hasil perhitungan posttest di dua kelas penelitian dapat dilihat pada tabel 2.

Tabel 2. Hasil Posttest Kelas Eksperimen dan Kelas Kontrol

\begin{tabular}{lccccc}
\hline \multicolumn{1}{c}{ Variabel } & N & Mean & Skor Max & Skor Min & Std. Deviasi \\
\hline Hasil Belajar Prostest Kelas Kontrol & 25 & 24,12 & 31 & 20 & 3,283 \\
Hasil Belajar Prostest Kelas Eksperimen & 25 & 30,4 & 34 & 27 & 2,550 \\
\hline
\end{tabular}

Rincian hasil yang diperoleh dari posttest yang dilakukan di kelas eksperimen yang menggunakan model pembelajaran kooperatif tipe Teams Games Tournament berbantuan permainan tradisional dari tabel tersebut menunjukkan bahwa rata-rata skor yang diperoleh siswa yaitu 30,4 dengan rata-rata nilai 76. Untuk kelas kontrol yang menggunakan model pembelajaran konvensional dari tabel di atas menunjukkan bahwa rata-rata skor yang diperoleh siswa yaitu 24,12 dengan rata-rata nilai 60,3 Dari data hasil posttest kelompok kontrol dan kelompok eksperimen tersebut dapat disimpulkan bahwa hasil belajar dalam kategori cukup tinggi.

Pengujian hipotesis dilakukan melalui nilai pretest dan posttest hasil belajar kelas eksperimen yang pembelajarannya menggunakan model Teams Games Tournament berbantuan permainan tradisional dan kelas kontrol yang menggunakan model konvensional. Uji hipotesis pada penelitian ini menggunakan Gain score Independent Sample Test melalui program SPSS versi 20.0 for windows. Adapun hasil uji hipotesis disajikan pada tabel 3. 
Tabel 3. Hasil Uji Independent Sample t-test (Hasil Belajar Siswa)

\begin{tabular}{llcccc}
\hline \multicolumn{5}{c}{ Indepedent Sample t-test } \\
\hline \multirow{2}{*}{ Hasil Belajar } & \multicolumn{1}{c}{ t } & df & Sig. (2-tailed) & Rata-rata \\
& Kelas Eksperimen & $-7,554$ & 48 & 0,000 & 30,4000 \\
& Kelas Kontrol & $-7,554$ & 45,229 & 0,000 & 24,1200 \\
\hline
\end{tabular}

Hasil analisis uji t menghasilkan statistik uji t sebesar -7,554 dengan probabilitas (sig.) sebesar 0.000 (probabilitas < alpha (0.05)) sehingga hipotesis penelitian diterima. Dengan demikian, dapat dinyatakan bahwa terdapat pengaruh model pembelajaran kooperatif tipe Teams Games Tournament berbantuan permainan tradisional terhadap hasil belajar siswa kelas IV SDN Klojen Kota Malang. Setelah dilakukan uji indepandent sample t-test yang menyatakan bahwa hasil belajar siswa pada posttest menunjukkan ada pengaruh model pembelajaran kooperatif tipe Teams Games Tournament berbantuan permainan tradisional terhadap hasil belajar siswa kelas IV SDN Klojen Kota Malang kemudian dilanjutkan dengan uji gain score untuk menghitung selisih hasil pretest dan posttest pada kelompok kontrol dan kelompok eksperimen. Adapun hasil perbandingan pretest dan posttest disajikan pada tabel 4.

Tabel 4. Hasil Uji Gain Score Dua Kelompok

\begin{tabular}{lcc}
\hline \multirow{2}{*}{ Keterangan } & Kelas Eksperimen & Kelas Kontrol \\
\cline { 2 - 3 } & N-Gain Score & N-Gain Score \\
\hline Rata-Rata & 0,5482 & 0,3698 \\
Minimal & 0,23 & 0,5 \\
Maksimal & 0,76 & 0,70 \\
\hline
\end{tabular}

Data hasil uji gain score tersebut menunjukkan bahwa skor rata-rata yang diperoleh siswa pada kelas kontrol 0,5482 dengan skor minimal yang diperoleh siswa yaitu 0,23 dan nilai maksimal 0,76. Sementara itu, pada kelas kontrol, untuk nilai rata-rata yang didapatkan siswa yaitu 0,3698 dengan skor minimal 0,5 dan skor maksimal 0,7. Dari uraian tersebut dapat disimpulkan perbandingan skor antara kelompok kontrol dan kelompok eksperimen yang didapatkan dari skor pretest dan skor posttest menunjukkan bahwa skor rata-rata yang diperoleh kelompok eksperimen lebih tinggi dibandingkan dengan kelompok kontrol.

\section{PEMBAHASAN}

\section{Pengaruh Model Pembelajaran Kooperatif Tipe Teams Games Tournament berbantuan Permainan Tradisional terhadap Hasil Belajar Siswa}

Hasil belajar siswa naik kelas eksperimen maupun kelas kontrol diperoleh dari hasil posttest yang terdiri dari soal-soal yang berkaitan dengan materi. Soal yang diberikan kepada siswa berfungsi sebagai suatu alat untuk mengukur pemahaman siswa mengenai materi yang telah diajarkan. Hasil belajar yang digunakan pada penelitian ini dari hasil tes tulis yang diberikan di akhir proses pembelajaran atau disebut dengan posttest. Pengujian hipotesis penelitian ini menggunakan Gain Score Independen Sampel t-test. Berdasarkan hasil penelitian diperoleh data hasil belajar dari uji gain score yang menunjukkan bahwa selisih hasil belajar pretest dan posttest antara dua kelompok tersebut menunjukkan bahwa terdapat perbedaan hasil belajar pretest dan posttest pada kelas eksperimen yang menggunakan model pembelajaran Teams Games Tournament berbantuan permainan tradisional dengan kelas kontrol yang menggunakan model konvensional.

Hasil uji hipotesis yang dilakukan menunjukkan bahwa ada pengaruh yang signifikan model pembelajaran kooperatif tipe Teams Games Tournament berbantuan permainan tradisional terhadap hasil belajar siswa kelas IV SDN Klojen Kota Malang. Hal ini dibuktikan melalui analisis data dari hasil uji hipotesis menunjukkan nilai signifikansi (2-tailed) 0,00 yang berarti penerapan model pembelajaran kooperatif tipe Teams Games Tournament berbantuan permainan tradisional memengaruhi hasil belajar siswa.

Penerapan model pembelajaran kooperatif tipe Teams Games Tournament berbantuan permainan tradisional memiliki dampak yang lebih baik dalam meningkatkan hasil belajar siswa. Hal terssebut dikarenakan pada pembelajaran dengan model Teams Games Tournament berbantuan permainan tradisional dapat menumbuhkan rasa kerjasama antar kelompok serta membuat siswa berpartisipasi aktif dalam proses pembelajaran. Pada model pembelajaran Teams Games Tournament berbantuan permainan tradisional siswa dapat belajar yang menyenangkan melalui permainan tradisional. Pernyataan tersebut didukung oleh pendapat dari (Shoimin, 2013) menyatakan bahwa penerapan model pembelajaran Teams Games Tournament dapat menumbuhkan kerjasama siswa dalam kelompoknya melalui kegiatan belajar yang menyenangkan sehingga memotivasi siswa untuk belajar secara aktif. Hal ini sejalan dengan pemikiran Vigotsky dalam (Ormrod, 2008) yang menyatakan bahwa permainan memungkinkan anak berkembang secara kognitif. Pembelajaran pada kelas eksperimen menekankan pembelajaran aktif dan bermakna. 
Pembelajaran yang dilakukan dengan menerapkan model pembelajaran Teams Games Tournament berbantuan permainan tradisional merupakan pembelajaran yang dilakukan r sambil bermain. Vigotsky (Ormrod, 2008) menyatakan bahwa permainan memungkinkan anak berkembang secara kognitif. Dengan demikian permainan tradisional yang dipadukan dengan model Teams Games Tournament dapat meningkatkan hasil belajar siswa dalam ranah kognitif, afektif, dan psikomotor. Permainan tradisional yang dipadukan dengan model pembelajaran Teams Games Tournament yaitu gobak sodor, bentengan, dan telepon kaleng. Dalam praktiknya permainan tradisional tersebut disesuaikan dengan materi pembelajaran. Permainan gobak sodor dan bentengan dapat menunjukkan variasi gerak dasar lokomotor dan non lokomotor, sedangkan permainan telepon kaleng dapat membuktikan bahwa bunyi mempunyai sifat merambat melalui zat padat. Dengan demikian, penerapan model pembelajaran Teams Games Tournament berbantuan permainan tradisional dapat memotivasi siswa dan membuat siswa lebih aktif dalam pembelajaran.

Permainan tradisional betengan, gobak sodor, dan telepon kaleng yang dipadukan dengan model pembelajaran Teams Games Tournament dilakukan siswa secara berkelompok. Belajar dalam kelompok dapat membantu siwa dalam memahami materi pelajaran. Siswa satu dengan siswa lain saling membantu dan bekerja sama untuk dapat menyelesaikan tugas yang ada. Bimbingan yang diberikan kepada siswa satu pada siswa lainnya ini merupakan proses scaffolding. Rosenshine \& Maister 1992 (Slavin, 2006) menyatakan bahwa Scaffolding menyediakan banyak dukungan kepada siswa selama awal mempelajari materi yang sulit dan kemudian menghilangkan dukungan ketika siswa sudah dianggap mampu untuk melanjutkan pembelajaran. Dalam penerapannya, model pembelajaran Teams Games Tournament berbantuan permainan tradisional menumbuhkan rasa kerja sama antar siswa dalam satu kelompok untuk mendapatkan hasil belajar yang baik.

Peningkatan hasil belajar yang diperoleh siswa melalui penerapan model pembelajaran Teams Games Tournament berbantuan permainan tradisional ini dikarenakan adanya motivasi belajar yang tinggi pada siswa untuk dapat bermain permainan tradisional serta untuk mendapatkan hadiah. Hadiah atau reinforcement merupakan suatu bentuk penghargaan yang diberikan guru kepada kelompok yang memenangkan permainan tradisional dan mendapatkan hasil diskusi terbaik. (Slavin, 2005) menyatakan bahwa reinforcement merupakan keterampilan dasar dalam mengajar sebagai konsekuensi yang memperkuat perilaku. Dengan adanya reinforcement mampu memotivasi siswa untuk dapat belajar dengan aktif didalam kelompoknya.

Berdasarkan uraian di atas, hasil belajar siswa pada penerapan model pembelajaran Teams Games Tournament berbantuan permainan tradisional lebih baik jika dibandingkan dengan hasil belajar siswa pada penerapan model pembeajaran konvensional baik dari kelas kotrol maupun kelas eksperimen. Hal ini dibuktikan dari uji gain score hasil belajar siswa pada pretest dan posttest di kelas eksperimen maupun kelas kontrol menunjukkan selisih yang berbeda. Selain itu, dari hasil uji independent sampe t-test menunjukkan hal yang sama yaitu terdapat perbedaan yang signifikan dari hasil belajar siswa yang diperoleh melalui posttest kelas kontrol dengan kelas eksperimen. Maka dapat disimpulkan bahwa hasil penelitian penerapan model pembelajaran kooperatif tipe Teams Games Tournament berbantuan permainan tradisional berpengaruh terhadap hasil belajar siswa.

\section{SIMPULAN}

Berdasarkan hasil penelitian yang diperoleh, maka kesimpulan dalam penelitian ini adalah ada pengaruh model pembelajaran kooperatif tipe Teams Games Tournament berbantuan permainan tradisional terhadap hasil belajar siswa kelas IV Sekolah Dasar. Berdasarkan pada berbagai temuan yang sudah dibahas pada bab hasil penelitian dan pembahasan, maka peneliti memberikan saran sebagai berikut. Pertama, bagi guru, khususnya guru sekolah dasar disarankan guru menggunakan berbagai model pembelajaran yang mampu menstimulus proses pembelajaran dengan baik sehingga tujuan dari pembelajaran dapat tercapai. Khususnya pemilihan model pembelajaran kooperatif tipe Teams Games Tournament berbantuan permainan tradisional karena memiliki pengaruh terhadap hasil belajar siswa. Kedua, bagi peneliti selanjutnya yang berminat pada topik model pembelajaran kooperatif tipe Teams Games Tournament disarankan menggunakan permainan yang lain dan menggunakan desain penelitian yang berbeda seperti Penelitian Tindakan Kelas agar dapat meningkatkan hasil belajar siswa. Ketiga, faktor pendukung dalam tercapainya keberhasilan pembelajaran juga perlu diperhatikan.

\section{DAFTAR RUJUKAN}

Amri, Sofan, Ahmadi, \& K, L. (2010). Proses Pembelajaran Kreatif dan Inovatif dalam Kelas. Jakarta: Prestasi Pustakaraya.

Andriani, T. (2012). Permainan Tradisional Dalam Membentuk Karakter Anak Usia Dini. Jurnal Sosial Budaya, 9(2). http://dx.doi.org/10.24014/sb.v9i1.376

Gee, \& James, P. (2008). Learning and Games. The Ecology of Games: Connecting Youth, Games, and Learning (Katie Salen, D. John, \& Catherine, eds.). Cambridge: MacArthur Foundation Series on Digital Media and Learning.

Hanurawan, F., \& Soetjipto, B. E. (2009). Pengembangan Buku Panduan Guru untuk Pembelajaran PKn SD/MI melalui Berbagai Model Cooperative Learning. Jurnal Sains Psikologi, 1(2), 1-14.

Happidin., \& Yenina. (2016). Pengembangan Model Permainan Tradisional Dalam Membangun Karakter Anak Usia Dini. Jurnal Pendidikan Usia Dini, 10(2), 201-212. https://doi.org/https://doi.org/10.21009/JPUD.102.01

Hosnan, M. (2014). Pendekatan Saintifik dan Kontekstual dalam Pembelajaran Abad 21. Bogor: Ghalia Indonesia.

Indrayani, S., Degeng, I. N. S., \& Sumarmi. (2017). Efektivitas Penggunaan Model Teams Games Tournament Berbantuan Media Kokami terhadap Hasil Belajar IPS. Jurnal Pendidikan: Teori, Penelitian, dan Pengembangan, 2(10),1321-1329. 
Istiqomah. (2016). Application of Cooperative Learning Model Teams Games Tournament (TGT) Type to Increase Activity and Results of Biology Learning in Class X-MIA 2, MAN-1 Pekanbaru 2015-2016 Academic Year. Proceeding of The $1^{\text {st }}$ UR International Conference on Educational Sciences.

Lusiana, E. (2012). Membangun Pemahaman Karakter Kejujuran melalui Permainan Tradisional pada Anak Usia Dini di Kota Pati. Journal of Early Childhood Education Papers, 1(1), 1-6.

Majid, A. (2014). Pembelajaran Tematik Terpadu. Bandung: PT. Remaja Rosdakarya.

Ormrod, J. E. (2008). Educational Psycology Developing Learner. Upper Saddle River: Merril Prentice Hall.

Rahayu, G. D. S., \& Nugraha, F. F. (2017). Effect of Cooperative Learning Model Type Team Game Tournament (TGT) on Cross-Cultural Skills in Learning Science Social Knowledge in Primary School. PrimaryEdu - Journal of Primary Education,3(2), 63-70.

Sanusi, N. M., \& Widyaningsih, F. (2014). Penerapan Model Pembelajaran Teams Games Tournament (TGT) untuk Meningkatkan Kemampuan Komunikasi Matematis Siswa pada Pokok Bahasan Pecahan. Jurnal Karya Pendidikan Matematika, 1(2), 17-23.

Shoimin, A. (2013). 68 Model Pembelajaran Inovatif dalam Kurikulum.Yogyakarta: Ar-Ruzz Media.

Slavin, R. E. (2005). Cooperative Learning Teori Risert dan Praktik. Bandung: Nusa Media.

Slavin, R. E. (2006). Educational Psycology: Theory and Practice. Boston: Allyn and Bacon.

Suaeb, S., Degeng, I. N. S., \& Amirudin, A. (2018). Meningkatkan Hasil Belajar IPS Siswa Kelas V melalui Penerapan Pembelajaran Kooperatif Model Teams Games Tournament (TGT) Berbantuan Media Tebak Gambar. Jurnal Pendidikan: Teori, Penelitian, dan Pengembangan, 3(1), 146-154.

Veloo, Arsaythamby, Md-Ali, Ruzlan, Chairany, \& Sitie. (2016). Using Cooperative Teams-Game-Tournament in 11 Religious School to Improve Mathematics Understanding and Communication. Malaysian Journal of Learning and Instruction, $13(2)$. 